\title{
A HUMÁN TUDOMÁNYOK ALAPKÉRDÉSEI ${ }^{1}$
}

\section{FOUNDATIONAL QUESTIONS OF THE HUMANITIES}

\author{
Kecskeméti Gábor \\ az MTA levelező tagja, kutatóprofesszor, \\ Magyar Tudományos Akadémia Bölcsészettudományi Kutatóközpont Irodalomtudományi Intézet \\ kecskemeti.gabor@btk.mta.hu
}

\begin{abstract}
ÖSSZEFOGLALÁS
A Magyar Tudományos Akadémia I. (Nyelv- és Irodalomtudományok) Osztálya 2017-ben olyan könyvsorozatot indított, amely három meghatározó fontosságú problémakörben kíván orientációs pontokat kijelölni és felmutatni: az osztály által művelt tudományágak és -területek tudomány- és ismeretelméleti alapkérdéseiben, társadalmi funkciójukban és a természettudományokhoz való viszonyuk problémáiban. A sorozat első kötete öt olyan tanulmányt közöl, amelyek szintetizáló igénnyel tekintik át, milyen megfontolások milyen ismeretelméleti pozíciót juttatnak ma a tudományos magyarázat két kulcsfogalmának, a megértésnek és a megértetésnek az osztály által felölelt hat nagy tudományág közül ötnek a tudományelméletében. A második kötetben - a szerkesztői bevezető után - nyolc írás a humán és a természettudományos gondolkodás közötti gondolati kapcsolatok (módszertani analógiák, közös problémák és szemléleti párhuzamok) négy fogalmi rendszerét mutatja be olyan páros esettanulmányokban, amelyeket különböző tudományterületek szakemberei készítettek.
\end{abstract}

\section{ABSTRACT}

In 2017, the Section of Linguistics and Literary Scholarship of the Hungarian Academy of Sciences launched a book series which aims at defining and providing points of departure for three key issues: questions of the epistemological and metatheoretical foundations of the disciplines conducted at the section, those of the social functions of these fields as well as their relationship to the natural sciences. The first volume contains five studies that survey, with synthetizing aim, in what ways epistemological considerations assign different positions to the two key concepts of explanation today, i.e. understanding and making someone understand, in five of the six major disciplines covered by the section. In the second volume, after the editorial introduction, eight essays present four conceptual systems of relationships (methodological analogy, common problems, or parallel approaches) between the thinking in the humanities and the natural sciences in parallel case studies prepared by specialists of different disciplines.

\footnotetext{
${ }^{1}$ A tanulmány a Tolcsvai Nagy Gábor (2017a és 2017b) könyvbemutatóján elhangzott előadás szerkesztett változata.
} 
Kulcsszavak: humán tudományok, magyarázat, megértés, hermeneutika, káoszelmélet, képi reprezentáció, nyelvi nativizmus, hálózatelmélet

Keywords: humanities, explanation, understanding, hermeneutics, chaos theory, pictorial representation, linguistic nativism, network theory

A Magyar Tudományos Akadémia I. (Nyelv- és Irodalomtudományok) Osztálya 2017-ben olyan könyvsorozatot indított, amely - az osztályelnök és sorozatszerkesztő Kertész András előszava szerint - három meghatározó fontosságú problémakörben kíván orientációs pontokat kijelölni és felmutatni: az osztály által mủvelt tudományágak és -területek tudomány- és ismeretelméleti alapkérdéseiben, társadalmi funkciójukban és a természettudományokhoz való viszonyuk problémáiban. Ezekről a túlbecsülhetetlen fontosságú kérdésekről olyan gondosan koncipiált tanulmánykötetek készülnek, amelyek egy-egy korábbi tematikus osztálykonferencia előadásainak továbbfejlesztett változatait közlik, a legmagasabb tudományos nívójú, ugyanakkor a tudomány iránt érdeklődő szélesebb közönség számára is világos gondolatvezetésű, befogadható terminológiájú tanulmányokat. A sorozat 2017-ben megjelent első két kötetét Tolcsvai Nagy Gábor szerkesztette. Az első darab - amelynek alapját egy 2015. novemberi konferencia teremtette meg - öt olyan tanulmányt közöl, amelyek szintetizáló igénnyel tekintik át, milyen megfontolások milyen ismeretelméleti pozíciót juttatnak ma a tudományos magyarázat két kulcsfogalmának, a megértésnek és a megértetésnek az osztály által felölelt hat nagy tudományág közül öt tudományelméletében. A második, egy 2016. májusi konferencia anyagából építkező kötetben - a szerkesztői bevezető után - nyolc írás a humán és a természettudományos gondolkodás közötti, különböző ismeretelméleti szintű, ám az eltérő területeken egyaránt hasznosítható gondolati kapcsolatok (módszertani analógiák, közös problémák és szemléleti párhuzamok) négy fogalmi rendszerét mutatja be olyan páros esettanulmányokban, amelyeket különböző tudományterületek szakemberei készítettek.

Meggyőző szerkesztői döntésnek bizonyult a megértés és a megértetés mai szemléleti alapjait áttekintő első kötet élére az irodalomtudományi magyarázatra vonatkozó elvi belátásokat tárgyaló Kulcsár Szabó Ernő-tanulmányt illeszteni. Az irodalomtudománynak a szövegeknek való jelentéstulajdonítás körében elért belátásai ugyanis élénk visszhangot keltenek nemcsak azokban a további humán tudományokban, amelyek ugyancsak textuális-verbális forrásokkal dolgoznak (nyelvtudomány, klasszika-filológia), hanem azokban is a világra mint jelentéses voltában szövegszerủen megalkotott és akként befogadható jelenségcsoportra tekintő szemléleti változásokat generáltak, amelyeknek kutatási területe nem(csak) szövegszerü (néprajztudomány, zenetudomány). A mindezeken a területeken ér- 
vényesülő szemléleti elvek hermeneutikai természete az irodalomtudományban elvégzett elméleti munka nyomán vált (és tehető) nyilvánvalóvá.

Kulcsár Szabó tanulmányának tudomány- és eszmetörténeti szemléje szerint a 20. század végére már számos nyelv- és személyiségelmélet az emberi lét ontológiai kereteként számolt a dialógussal és a dialogicitással. Mihail Bahtyin a beszédaktus-elméleteket vitte egy lépéssel tovább, amikor úgy vélekedett, hogy minden kijelentés egy magasabb szintü beszélgetés beszédaktusa; mások arra figyelmeztettek, hogy minden emberi szó egy másik lény létét feltételezi, minden kijelentés legalább két tudat közötti határhelyzetben áll. A személyiség, az én, a self is valójában már puszta konstitúciójában mindig plurális és szociális jelenség, amelynek tevékenységei dialógusokban állnak, amelyek jóval annak előtte vették kezdetüket, mielőtt verbális aktus(ok)ra kerülne sor. Ezeknek a nyelv- és személyiségelméleteknek a természetes irodalomtudományi partnere a hermeneutika. A dialogikus hermeneutikai tapasztalat alapvető belátásait Hans-Georg Gadamer Was ist Wahrheit? címú írása (1957) alapján bontja ki a tanulmány: „Nincs az a kijelentés, melyet egyedül az általa feltárt tartalomra nézve meg lehetne érteni, ha a kijelentést a maga igazságában akarjuk megragadni. Motivált minden kijelentés. Minden kijelentésnek vannak olyan előfeltételei, amelyeket nem jelent ki. Egy kijelentés igazságát csak az képes valóban felmérni, aki ezeket az előfeltételeket is odagondolja. [...] Nem az ítéletnek, hanem a kérdésnek van elsőbbsége a logikában, ahogyan azt a platóni dialógus és a görög logika dialektikus eredete történetileg is tanúsítja. A kérdésnek a válasszal szembeni elsőbbsége azonban azt jelenti, hogy a kijelentés lényegileg válasz. Nincs olyan kijelentés, amely ne egyfajta választ jelenítene meg. Ezért nem létezik valamely kijelentésnek olyan megértése, amely ne annak a kérdésnek a megértéséből nyerné a kijelentés egyedüli mércéjét, amelyre az válaszol." Mindebből a magyarázat kommunikációs funkciójára nézve világos következtetések adódnak. Kulcsár Szabó Ernő hangsúlyozza, hogy tudásunkat/a tudást nem átadjuk, hanem a tudás megtörténik velünk. Nincs valamely statikus, tölünk független tudás, amelyet csupán közvetítőként, azt érintetlenül hagyva továbbíthatnánk, hanem tudásunk a maga dialogikus nyelviségében mindig létrejön. Ebből az is következik, hogy „hermeneutikai értelmezésben a nyelv csak a beszélgetésben, a beszéd totalitásában mehet végbe”, s így ,a mindig társiasságra ráutalt, hangzó élőbeszédiség a nyelv ideáltipikus formája, ahol a világot nem kijelentések rendezik érthető alakba, hanem mindaz, amit világnak nevezünk, egyáltalán csak a beszélgetésben mutatkozik meg elöttünk”. A szövegekről való tudásunk is ilyen: ,... az irodalomtudományban bizonyosan terméketlen minden olyan igyekezet, amely a konstatív és a performatív beszédcselekmények elkülönítésére irányul”. A jelentés , a közlés eredeti formában felderíthetetlen igényét megszólaltatja, és a maga potencialitásából parciálisan valóra váltja”. Az esztétikai tapasztalat értelmezését sem alapozhatja meg a valóságos és az esztétikai lét vagy a valódi és az imaginárius világ elválasztottsága, a mü nem szigetelhető 
el mindössze a tetszés tárgyaként a közlés funkció- és hatásösszefüggéséből. Ennek az esztétikai megkülönböztetésnek az útja nem vezethetne másfelé, csakis arra, hogy az irodalom voltaképpeni történetiségét kivezessék az irodalmiságból, és más történetek illusztrációjává fokozzák le. Németh G. Béla, Barta János, Király István emlékezetes, iskolateremtő hatású tanulmányai szolgáltatnak példákat arra, amikor a mozdulatlan hagyomány autoritásának ideológiája helyett a konstitutív történés „felforgató” egyedisége érvényesült az irodalomtudományban. Az ilyen „müértelmezések a maguk történeti pontszerüségében is érvényesebb irodalomtörténetet írnak, mint a korszak- és folyamatrajzban megalapozott irodalomtörténeti kézikönyvek", amelyek gyakran mindössze a müvet övezö körülmények és események krónikásai.

A magyarázat nyelvtudományi pozíciójáról, illetve a nyelvtudományi magyarázat pozíciójáról Tolcsvai Nagy Gábor által megállapított alapelvek teljes összhangban vannak az irodalomtudományiakkal. Eszerint a tudományos magyarázat „,nem a megértés mủvelete, hanem a megértés, az értelmezés eléréséhez vezető folyamat megformált bemutatása, leírással, levezetéssel, érveléssel a meghatározás és leírás mellett". A megértetés dialogikus müvelet. A nyelvtudományi magyarázat elméletfüggő, három mai irányzata a hagyományos besoroló, a formális és a funkcionális nyelvelmélet. A hagyományos besoroló az újgrammatikus és a saussure-iánus strukturalista elmélet szintézise. A formális nyelvelmélet chomskyánus alapelvei szerint a nyelvi tudás genetikailag kódolt, univerzális grammatika; hogy mit is jelent pontosan ez a nyelvi nativizmus, arra a másik tanulmánykötet két esettanulmánya kapcsán még vissza kell térnünk. A funkcionális nyelvelmélet szerint a nyelvi tudás tanult, szerzett ismeret, amely az absztrakció, sematizáció, kategorizáció, szimbolizálás képességei alapján alakul ki; a nyelv részben egyetemes, részben kultúraspecifikus; a nyelvészet nem axiomatikus és deduktív, nem a természettudomány analitikus alapjain nyugszik. A másik tanulmánykötet bevezető tanulmányában Tolcsvai Nagy - az annak címében foglalt módszertani analógiára, közös problémára és szemléleti párhuzamra egyszerre adva példát - közvetlen párhuzamot von az irodalom- és a nyelvtudomány felismerései között, megállapítva, hogy a hermeneutika strukturalizmussal szembeni metaelméleti kerete olyan, mint a funkcionális kognitív nyelvészet fellépése a generatív nyelvészettel szemben.

A klasszika-filológia területén Tamás Ábel vonja le hasonló tudományelméleti megfontolások konzekvenciáit. Tanulmánya a filológiai kommentár müfajával foglalkozik. Tétele, hogy a kommentárnak sincs közvetlenebb hozzáférése a kommentált szöveghez, mint más szakmai magyarázatoknak, vagyis a benne foglalt magyarázat nem elözi, nem elözheti meg az értelmezést. Inkább az - irodalomtudományi gondolkodás által ismertté tett - üres helyek interpretatív kitöltésének gyakorlataként fogható fel. A szöveggondozás mủveleteihez hasonlóan ez az értelemgondozás müvelete. 
A néprajztudományban érvényesnek tekintett magyarázó elvek és eljárások pazar bőségére nyílik rálátás Borsos Balázs tanulmányából. Az „adatok” (például a néprajzi atlasz anyagának) megközelítése történhet belülröl, a kultúrák saját kategóriái szerint vagy kívülről, az európai tudománytörténet eleve összehasonlító szempontú kategóriáival; elmondva egy, az egyénről vagy a közösségről szóló történetet az idegen vagy a saját kultúra köréből; felvállalva vagy eltüntetni akarva a kutató részvételének nyomait. A néprajztudomány szemléleti rendjeinek tipologizáló csoportosítása arról tanúskodik, hogy mára messze túlsúlyba került a kutatáselméletekben és a kutatói gyakorlatokban az antropológiai jelenségek olyan szerveződési formáinak felismerése, amelyek mind az analizált univerzumot, mind az analizáló eljárásokat szövegszerü vagy szöveggel analóg voltukban teszik leírhatóvá. A kognitív antropológia a kultúra saját kategóriái szerint szervezett narrációt ad, mégpedig elsődlegesen a materiális jelenségeket elrendező emberi elméről. A szimbolikus antropológia szerint a kultúra egésze szöveg, amelynek elemzése az irodalomkritikához közelít. Az interpretatív antropológia szemléleti alapállása szerint a kultúra párbeszéd, amelynek az antropológus (sőt az olvasója) is a résztvevője. Posztmodernként nevezhető meg az az antropológia, amely a kultúraleírásnak ezt a participációs természetét már olyan meghatározónak látja, hogy szerinte nem is a leírás tárgya, hanem csupán az antropológus és az ô írásmúvének a tulajdonságai az érdekesek, az antropológia tulajdonképpen az irodalom részterülete. Az együttmüködő antropológia ott nyeri vissza a társas dimenziót, hogy az értelmezésben találja meg a közösségi müködést, például abban, ahogyan a szociális média kommentáló aktusai is felhasználásra kerülnek a néprajztudományi megértésben. Amivel természetesen megint egy, az irodalomtudományban használatos szemléleti keretnek, az értelmező közösségek elméletének a közelébe kerülünk.

A zenetudományi magyarázat egészen sajátos hermeneutikai pozíciójáról Tallián Tibor írt esettanulmányt. Richard Wagnertől idézi fel azt a gondolatot, amely akár a német hermeneutikai gondolkodás bármely klasszikusától származhatna: nem a megértés az előfeltétele a müvészet iránti szeretetnek, hanem fordítva: a megértés emberi szeretetből - rokonszenvből, részvétből - táplálkozik. Ugyanakkor Wagner a maga zenéjének jelentés-központúságát kiterjesztette a zenetörténet egészére. Önértelmezése szerint Beethovennek a 9. szimfóniában végrehajtott, a hangszeres zene jelentését a szöveggel gazdagító lépését fejlesztette tovább a dráma müfajában, megteremtve a Gesamtkunstwerk összmüvészeti komplexumát. Wagnernek ez a felfogása Nietzsche szerint apologetikus aktus. Megjegyzéséből kibontva lehetséges, sőt jelentésteljes egy egészen más értelmezés is: a zenét nem a szövegböl, hanem a zenéből értjük meg - sőt a zene szövegének megértéséhez is csak a zene felöl vezet út.

A tudományközi diskurzus lehetőségeit megmutató - nem annyira multi-, mint inkább interdiszciplináris horizontú - másik tanulmánykötet élére a szerkesztő írt 
e diskurzus kommunikációelméleti és tudományfilozófiai feszültségeit megmutató tanulmányt. Tolcsvai Nagy Gábor nyomatékosan hangsúlyozza, hogy nincs tudományos újítás nyelvi innováció nélkül, a nyelv nem puszta eszköz, hanem valódi konstitutív erő mind a kutatásban, mind annak megjelenítésében. De még e pozíciókijelölés után is mély és összetett kérdések özöne vár válaszra. Folyik-e közös jelentésképzés, azaz értelemalkotás a tudományos kommunikációban, vagy csak egyirányú közvetítés, mediatizálás? A ráció irányítja-e a tudományos kommunikációt objektív instanciaként, és/vagy dialogikus megértő müveletek történnek? A tárgyra irányulás módja a tárgyiasítás vagy a konstruálás? Ha az utóbbi - ami felé a tanulmány nyilvánvalóan orientálja az olvasót -, akkor a nyelv nem az eszköze, hanem a közege a megismerésnek és a kommunikációnak. Ez a kommunikációs struktúra autopoétikus elemeket tartalmaz: mind a tudós, mind a tudományos közösség önalkotásának megkerülhetetlen tényezöje. Bizonyos terminusok (például a struktúra szó és fogalom) nem tekinthetők összemérhetetlennek a különböző tudományágakban, más esetekben viszont egy-egy tudományos magyarázat nyíltan metaforizál egy másik tudományból vagy a mindennapi nyelvből vett fogalmakkal. A konstruáláson alapuló kommunikációs stratégiák és hálózatok inkább nyitottak a tudományok közötti átjárásra, vállalva az analógiás metaforizálásban rejlő veszélyeket és egyúttal a lehetőségeket is. A kötet nagyrészt ilyen tanulmányok foglalata.

A gondolatmenetek az interdiszciplináris fogalomalkotás és következtetés lehetőségeit megnyitó négy szemléleti forma, a kaotikus dinamika, a képiség, a nativizmus és a hálózatok köré rendeződnek. A kaotikus dinamikának az analízisben való alkalmazására egy irodalom- és egy társadalomtudós tanulmánya ad példát. S. Varga Pál Diltheyt idézi, akitől fogva közhely a természettudományok nomotetikus, a szellemi jelenségek vizsgálatának idiografikus módszeréről beszélni: az általános törvényszerüségek kiemelése az egyedi, egyszeri jelenségek megértésével áll szemben. „Egy irodalmi alkotás jelentését és jelentőségét ugyanis alapvetően az határozza meg, ami egyedi benne; még az általánosítható vonások is csak e különbözőség kontextusában nyernek értelmet.” Irodalmi müvek egyes csoportjai mégis az emberi viszonyok olyan modelljét alkotják meg, amelyben az okok és a következmények arányossága, a lineáris kauzalitás érvényesül; a realizmusnak, a naturalizmusnak ez programtörekvése volt, míg más esetekben nem az irányzatosság, hanem a müfajiság hat ebbe az irányba, például amikor a detektívregény elkerülhetetlen hermeneutikai közegét épp a kauzalitásnak a széttartó és megtévesztő látszatok mögötti felismerése adja. Káoszelméleti vizsgálat olyan müvekre irányulhat, amelyekben a cselekmény ugyan determinisztikus viszonyrendszerben áll, fázisai azonban a nem lineáris kauzalitás elve szerint következnek. A tanulmány négy irodalmi mü elemzését építi fel erre a kaotikus dinamikára (Antigoné, Hamlet, Bánk bán, A rajongók). Fokasz Nikosz tanulmányában ugyanezek a káoszelméleti összetevők komplex szociális rendszerekben 
mutatkoznak meg, mint a növekedés, a rezgőmozgás, a ciklusok, a gerjesztések társadalmi és gazdasági jelenségei.

Pléh Csaba a képi analógia tudománytörténetének izgalmas metszetét alkotja meg, amikor azt bizonyítja, hogy ugyan a látvány egészlegessége és az izomorfizmus mára meghaladott fogalmak a pszichológia történetében, azonban a mai kognitív elméletekben is jelen van (másként) az izomorfizmus gondolata. Nyíri Kristóf általánosabban beszél a képek kognitív szerepéről és a képi reprezentációnak a gondolkodás történetében betöltött helyéröl. A képi metaforák sohasem szoríthatók a puszta stíluselem szerepkörébe, hanem kikerülhetetlen gondolati eszközként múködnek, a legszorosabb kapcsolatban vannak a mentális képi sémákkal, s mindezt a nyelv történetiségéről való gondolkodás egy szakaszában világosan kifejezésre is juttatta a nyelv vizuális eredetét tételező kratilikus nyelvelmélet. A mentális képek nemcsak a konkrétra és egyedire vonatkozhatnak, hanem generikus képekként is funkcionálnak.

Nyelvész és evolúcióbiológus egyaránt a nyelvi nativizmusnak az előző kötet kapcsán már érintett kérdéseiről írt tanulmányt. Surányi Balázs azt a kérdést teszi fel, hogy pontosan mi is volna a velünk született nyelvi tudás a generatív nyelvelmélet szerint. Chomsky Descartes-ra és a Port-Royal racionalista filozófiai nyelvtanára utalt elődeiként - ő maga azonban a nyelvi rendszer velünk született magját elsősorban nem tudásként, hanem a grammatikai rendszer elsajátítására szolgáló kognitív képességként határozza meg. Ha valaki ezzel az innátista nyelvfelfogással szemben emergentista alapelvre helyezkedik, akkor neki viszont a nyelvelsajátítást végző gyermek tanulási képességeit illetően kell többet feltételeznie, mint a nativistának. Szathmáry Eörs a nyelv evolúciós eredetének problémáját elemezve indul ki egészen hasonló tételezésekből, és jut szinergikus eredményekre. A nyelv szimbolikus referencia és összetett szintaxis kombinációjaként fogható fel, aminek alapján az agy és a nyelv koevolúciója feltételezhető. Egyes újítások, amelyeket eleinte minden egyednek meg kellett tanulnia, később genetikailag kódolódtak - de nem az egyes szabályok, hanem az azok feldolgozására való képesség és hatékonyság.

A kötet két záró tanulmánya hálózatelméleti megközelítést választ. Csermely Péter a természetben előforduló hálózatok szerkezetének és átalakulásainak általános vonásaival foglalkozik, Ritoók Zsigmond pedig a homéroszi jelzők, szintagmatikus formulák és elbeszélésszerkezetek (tipikus helyzetek) kombinációinak hálózatait írja le, különösen nagy megvilágító erővel alkalmazva a hálózatos megközelítést a görög nyelvi rendszer és poétikai eszközkészlet határterületének értelmezésében.

Hogy a megértés és a megértetés egymástól elválaszthatatlan folyamatok, annak felismerésére vonatkozólag már az ifjabb Seneca erkölcsi leveleinek egyik közismert aranymondása idézhető: „homines dum docent discunt”, ,az emberek tanulnak, miközben tanítanak" $(I, 7,8)$. Ma sem igen mondhatunk lényegibbet és 
érvényesebbet a tanulás és a tanítás mesterségéről, mint Apáczai Csere János Joachimus Fortius latin müvét magyar dialógusban feldolgozó 17. század közepi munkája, a Tanács. A docendo discimus évezredes szellemében szólt, amikor kifejtette, hogy a tanítás a tanulás leghatékonyabb eszköze: „Mihelt Isten segedelméből az tudomány dolgában valami küs ítéletet tehetsz, azon igyekezzél, hogy napotló-napestig taníthass. [...] Ha azon egy dolgot tízszer eltaníttod, többet tanulsz, mintha sok időkig fonnyasztottad volna magad az otthon olvasással. Én sokszor sokat olvastam, melyre ha egy holnap múlva ráfogtál volna, azt sem tudtam volna megmondani, kiket olvastam. De az kikre másokat valaha tanítottam sok ízbe, azoknak emlékezeteket az halál üti ki fejemből. Sőt még most is úgy tudom őköt majd, mint az tíz ujjomot." Ugyancsak Apáczai Csere idézte $A$ bölcsesség tanulásáról szóló szónoklatában Platón felismerését arról, hogy minden más tudományág elsajátításában élesebb elméjúek azok, akiknek a matematikához tehetségük van, sőt hogy a politika és az etika sem egyéb, mint a jó cselekedetek és nyilvános ténykedések meghatározása észszerüség, arány és egybevágóság tekintetében.

Az MTA I. Osztályának könyvsorozatában megjelent első két kötet ugyanezekre az alapvető belátásokra figyelmeztet, amikor a textuális-verbális és a mentális szerkezetek közötti legszervesebb kapcsolatot, valamint a tudomány tág egyetemének bármely diszciplínájában és a nyelvi-szöveges ismeretrendezés müveleteiben megnyilvánuló analógiás viszonyok megkerülhetetlen voltát hangsúlyozza. A tanulmányok kivételesen magas, éspedig egyenletesen magas színvonalon rögzítik azokat a hermeneutikai és tudományelméleti sarokpontokat, amelyek a humán tudományok ismereti és kommunikációs pozícióit meghatározzák. Egész tudományszakok önreflektáltsági mértéke ritkán jut ilyen termékeny magaslatra, a diszciplínák metaelmélete ritkán hoz ilyen gazdag termést, mint a megjelent két kötetben. A kezdeményezés - ismételjük - túlbecsülhetetlen fontosságú.

\section{IRODALOM}

Apáczai Csere J. (1975): Magyar logikácska és egyéb irások. (Kiad., bev., jegyz. Szigeti J.) Bukarest: Kriterion Kiadó

Tolcsvai Nagy G. (2017a) (szerk.): Megértés és megértetés. A magyarázat a bölcsészettudományokban. Budapest: Gondolat Kiadó

Tolcsvai Nagy G. (2017b) (szerk.): A határok átlépése. Módszertani analógiák, közös problémák és szemléleti párhuzamok a humán és a természettudományos gondolkodásban. Budapest: Gondolat Kiadó 